$\tau_{0}>2 \cdot 10^{-9}$ sec., in agreement with the results of other observers ${ }^{4}$. The high value of the mean energy $\left(\sim 10^{10} \mathrm{eV}.\right)$ of $\mu$-mesons at this altitude indicates that the average energy of production of the $\mu$-mesons, or of the $\pi$-mesons of which they are the decay products, is large compared with the value $\bar{E}$ given above. This is consistent with the assumption that the $\mu$-mesons result from the much more energetic disintegration stars produced in the high atmosphere.

${ }^{2}$ Rochester, G. D., Rev. Mod. Phys., 21, 20 (1949). Jánossy, L., and Rochester, G. D., Proc. Roy. Soc., A, 183, 181 (1944).

Occhialini, G. P. S., and Powell, C. F., Nature, 162, 168 (1948).

- Burfening, J., et al., Phys. Rev., 75, 382 (1949).

- Camerini, Muirhead, Powell and Ritson, Nature, 162, 433 (1948).

'Harding, J. B., Lattimore, S., Li, T., and Perkins, D. H., Nature, $168,319(1949)$.

- Harding, J. B., Nature, 163, 440 (1949).<smiles>[111InH]</smiles>

\section{ANNUAL REPORT OF THE FORESTRY COMMISSIONERS}

$\mathrm{T}$

HE report of the Forestry Commissioners for the year ending September 30, 1947 (London : H.M. Stationery ONP ; 1948), covers the first complete year of thpepost-war forestry programme. Forest policy canye under review in the House of Commons in Nopnfoer 1945 and again in October 1946. On thip latter occasion the Minister of Agriculture and Fis Feries made an important announcement which mas, in fact, a full statement on forestry.

The opening portion of this statement merits careful study, and runs as follows: "On 30th November last year I made a statement in this House on Government Forest Policy. After careful and detailed study, the Government were impressed with the necessity, as a safety measure, apart from all other considerations, to rebuild our reserves of standing timber as quickly as possible. The Government were also impressed with the possibilities that systematic forestry and afforestation held out for the better utilisation of large areas of poor land, and increased employment in healthy rural surroundings for quite a considerable body of people. We proposed, therefore, at that time to ask the Forestry Commission to prepare for what we regarded as largescale action. My right hon. Friend the Chancellor of the Exchequer readily agreed to replenish the Forestry Fund by some $£ 20$ million during the five years 1946-50. The first instalment of that figure appears in the Estimates for the current financial year. This sum of $£ 20$ million is expected to provide for the afrorestation and replanting of something like 365,000 acres by State action and by assistance to owners of private woodlands, for the acquisition of land, for increased facilities for education, training and research into all branches of forestry, for up-todate houses for forestry workers, and for national forest parks; , and in addition, of course, the maintenance and development of the large areas of young plantations already established by the Forestry Commission."

It is common knowledge that the First World War considerably depleted the woodlands of Britain --practically all privately owned and grown woodlands. 'I'he Second World War has nearly cleared all the conifer areas, and the hardwood areas since the close of the War are now bearing the brunt of home fellings to a dangerous extent. It was the tardy recognition by the Government in 1919 of our almost total dependence on imports of the soft-wood timbers which caused the Forestry Bill to be passed in the House of Commons.

We are in whole agreement with the Minister in his belief that timber will remain an essential raw material for industry for a long time. But his reason for speeding up planting operations in Great Britain --because in the great forests from which the over. seas supplies had come the growth was not keeping pace with the depletion-is a sorry statement for a Minister of State to make on the forest administration of the Colonial Empire (it would not be true of India, but she is no longer in question). It is true the forests have been regarded mainly from the point of view of luxury timber producers, worked to this end by timber merchants, the Government taking absurdly small royalties for a produce which belonged to the people of the country it was ruling.

The report also deals with the dedication scheme for the owner of private woodlands. But since the report was written it would appear that some modifications will be necessary in the Commission's original ideas on this subject.

The following programmes are of interest for the five-year period 1946/47-1950/51. The planting programme is : England, 118,400 acres; Scotland, 123,400 ; Wales, 48,200; private forestry, 75,000. Total, 365,000 acres. The land acquisition programme is: England, 420,000 acres; Scotland, 330,000 ; Wales, 176,000. Total, 926,000 acres-or nearly a million acres in the five years.

The Commission may be congratulated on having produced a concrete plan which can be worked to without the ambiguities which are overshadowing so much of the piecemeal, so-called town-planning and other operations throughout Great Britain. Some of these latter are in the hands of more than one controlling or advisory authority; and the conflicting interests thus engendered appear, in some cases, to be dangerously imperilling the future food-raising possibilities by taking fertile agricultural land for building or new road work and so forth.

\section{NEW SOUTH WALES UNIVERSITY OF TECHNOLOGY NEW APPOINTMENTS}

TN connexion with the founding of the New South 1 Wales Unjersity of Technology (see Nature, July 30 , p. 195) appointments in the University have been made as follows.

Chair of Electrical Engineering: $M r . H . J$. Brown. For the past two years Mr. Brown has been acting assjotant director of the University of Technology and co-ordinator of research in the Technical Education Department. He will be responsible for the co-ordination of research in the new University. He graduated at Sydney, and has worked in the research labora. tories of Amalgamated Wireless and as an electrical engineer in the Tasmanian Hydro-Electric Commission. During the War he became principal research officer in the Council for Scientific and Industrial Research and was one of the leaders in radar research and development.

Chair of Architecture: $M r . F . E$. Towndrow. Mr. Towndrow is at present head of the Department of 
Architecture in Sydney Technical College and Vernon Memorial lecturer on civic architecture in the University of Sydney. Before taking this he was senior architect to the Ministry of Works in London, and controller of experimental building development (Great Britain). He has made extensive studies in Europe, has exhibited in the Royal Academy and is the author of a number of books on architecture and planning. $\mathrm{He}$ is a member of the Council of the Town and Country Planning Association, London, and was for several years hon. secretary of the Arts Committee of the Royal Institute of British Architects.

Registrar: Mr. J. C. Webb. A graduate of the University of Wales, Mr. Webb was engaged there in lecturing and in research on mining problems prior to going to Australia. Since 1946 he has held the position of head of the Mining Engineering Department of the Technical Education Department and has organised courses of mining instruction throughout New South Wales. In this capacity he was responsible for the establishment of the first coal-mining engineering degree course in Australia, together with a valuable scholarship scheme to provide financial assistance to students in the course. Mr. Webb is keenly interested in students' welfare and has taken an active part in the organisation of the social and sporting activities of students in the new University.

Chair of Chemical Engineering: Dr. J. P. Baxter, O.B.E. After graduating at Birmingham, Dr. Baxter won a Priestley research scholarship (1925-27) and later a James Watt research fellowship (1927-28) of that University during investigations in mechanical engineering and chemistry for which he was awarded the Frankland Medal. In 1928 he was appointed to the research staff of the General Chemicals Division of Imperial Chemical Industries, Ltd., becoming research manager in 1936 and director of the Division, in charge of their research laboratories, in 1945. Dr. Baxter has been connected with the development of many new chemical products such as polyvinylchloride, 'Gammexane' and organic fluorine compounds, together with a comprehensive programme of research into chemical engineering problems. During the War he was responsible for intensive researches on chemical warfare problems and collaborated on the chemical side of the atomic energy programme. In this connexion Dr. Baxter, at the request of the British Government, went to the United States in 1944 to join the American team working on atomic energy at Oak Ridge, and remained on this work until after the War. For his work on atomic energy development he was awarded the O.B.E. in 1945 .

Chair of Mining Engineering : Dr. D. W. Phillips. Dr. Phillips is a certificated colliery manager, and has served as an officer of the Safety in Mines Research Board, first as a mining engineer and geologist and later as chief mining engineer. In this capacity he was responsible for the direction of research on problems of haulage, subsidence and roof control in mines, and of shotfiring in coal mines. In 1943, he was appointed principal scientific officer to the Safety in Mines Research Board and, following the nationalization of the British coal industry, was appointed chief safety engineer to the National Coal Board. A graduate of the University of Wales and a Ph.D. of Cambridge, Dr. Phillips has established a high reputation as an authority on roof control in mines, and has published a large number of papers on the subject in British and European journals.
Chair of Applied Chemistry : Dr. A. E. Alexander. A fellow of King's College, Cambridge, Dr. Alexander is at present assistant director of research in the Department of Colloid Science, Cambridge. He was awarded the Ramsay Memorial fellowship in 1937 and the Rockefeller travelling scholarship in 1939 , the latter enabling him to work in the Department of Medical Chemistry in the University of Uppsala with Prof. T. Teorell. He was the Tilden lecturer of the Chemical Society in 1947. He has been engaged in research and teaching at Cambridge since 1935, chiefly in the field of surface chemistry, polymers and colloid chemistry. During the War he did research for the British Ministry of Aircraft Production and the Petroleum Warfare Department, working on polymers, aluminium soaps, camouflage, and rubber substitutes. In the industrial field Dr. Alexander has been adviser to industrial undertakings, particularly in connexion with paints, emulsions, soaps and detergents. $\mathrm{He}$ is the author of a large number of publications on colloids, surface chemistry and poly. mers and has recently particularly concerned himself with the effect of the surface activity of substances on their microbiological and drug action.

\section{NEW SEISMIC STATION AT GALERAZAMBA, COLOMBIA}

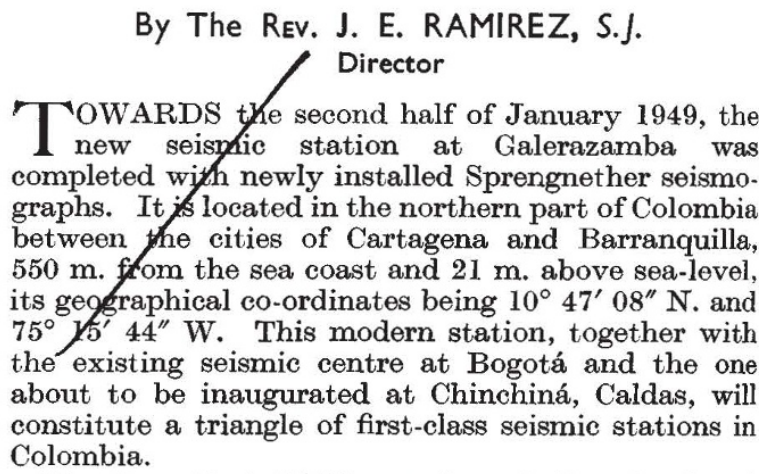

The idea of establishing such a station developed during a conversation between Dr. Carlos Gómez Martínez, director of Sección Salinas del Banco de la Republica, and myself in the spring of 1945. The project, purposes and advantages of a seismic station at Galerazamba were later outlined and explained in detail by Dr. Martínez to the board of trustees of the Banco de la República, which gladly gave full approval to the project. The United States representatives of the seismic programme in the Central and South American Republics, Mr. Franklin P. Ulrich and Mr. Edward P. Hollis, added a new impetus to the project during their visits to Bogotá in 1946 and 1947, respectively. 'The up-to-date seismic equipment was ordered in 1947.

The plans and specifications employed in the construction of the seismic station were prepared by F. A. and Arthur Stauder of Saint Louis, Mo. The seismic station is a one-story concrete block building, without basement, the dimensions of the exterior walls being $9.60 \mathrm{~m}$. for the length of the façade, $10.20 \mathrm{~m}$. the sides and $3.60 \mathrm{~m}$. in height. Besides the recording, seismometer and dark rooms, the building is provided with an observation room, a battery room and an office. Fibreglass insulation 